\title{
A Rare Side Effect of Ibrutinib: Tumor Lysis Syndrome
}

\author{
Ibrutinibin Nadir Bir Yan Etkisi: Tümör Lizis Sendromu
}

Erman OZTURK ๑, IsII ERDOGAN OZUNAL ๑

Ethics Committee Approval: Not applicable.

Conflict of Interest: The authors declare that they have no conflict of interest.

Funding: None.

Informed Consent: Informed consent was taken.
Cite as: Ozturk E, Erdogan Ozunal I. An unexpected side effect with ibrutinib: Tumor lysis syndrome. Medeni Med J. 2021;36:176-9.

\begin{abstract}
Chronic lymphocytic leukemia (CLL) is a progressive disease with an indolent course, and tumor lysis syndrome (TLS) is rarely seen in CLL. Ibrutinib is a novel bruton kinase (BTK) inhibitor increasingly used in CLL treatment. Ibrutinib has significant side effects such as atrial fibrillation, bleeding, diarrhea, and infections. However, TLS is reported rarely with ibrutinib treatment. This report focuses on a 69-year-old female patient diagnosed with relapsed CLL who developed grade 4 TLS after ibrutinib monotherapy. The patient developed TLS on the third day of ibrutinib treatment necessitating discontinuation of the treatment and initiation of hemodialysis and supportive care. Ibrutinib treatment was re-initiated at a daily dose of $140 \mathrm{mg}$ therapy after an interval of seven days, and then any additional side effect was not seen. Tumor lysis syndrome secondary to ibrutinib has been reported in an increasing number of cases. There is currently no information on managing adverse effects of TLS attributed to ibrutinib. Consequently, ibrutinib treatment of this patient was not terminated, and restarted after a short interval. It must not be forgotten that TLS secondary to ibrutinib treatment may be rarely seen, and can be life-threatening. Treatment with ibrutinib should be initiated in consideration of this side effect, and the development of complication of TLS may not necessitate discontinuation of ibrutinib treatment.
\end{abstract}

Keywords: Chronic lymphocytic leukemia, CLL, Ibrutinib, Tumor lysis syndrome

öz

Kronik lenfositik lösemi (KLL) yavaş seyirli, indolen bir hastalıktır ve seyrinde tümör lizis sendromu (TLS) görülmesi nadirdir. Ibrutinib, KLL tedavisinde giderek daha fazla kullanılan yeni bir Bruton kinaz (BTK) inhibitörüdür. Ibrutinib tedavisinin atriyal fibrilasyon, kanama, ishal ve enfeksiyon gibi önemli yan etkileri vardır. Bununla birlikte, ibrutinib tedavisi ile TLS nadiren bildirilmektedir. Bu olguda KLL nüksünden sonra ibrutinib monoterapisi uygulanan ve grade 4 TLS geliştiren 69 yaşındaki bir kadın sunulmaktadır. Ibrutinib tedavisinin 3. gününde TLS gelişen hastanın ibrutinib tedavisi kesilerek, hemodiyaliz ile destekleyici tedavi uygulandı. Ibrutinib tedavisi, yedi günlük bir ara verildikten sonra $140 \mathrm{mg}$ dozunda yeniden başlatıldı ve ek yan etki görülmedi. Ibrutinibe bağlı tümör lizis sendromu artan sayılarda rapor edilmektedir. Ibrutinibe bağlı TLS yan etkisinin yönetimi hakkında bilgi yoktur. Bu hastada ibrutinib tedavisi sonlandırılmadı ve kısa bir aradan sonra tekrar başlandı. Tümör lizis sendromunun Ibrutinibe bağlı nadiren görülebileceği ve yaşamı tehdit edebileceği unutulmamalıdır. Ibrutinib tedavisine bu yan etki göz önünde bulundurularak başlanmalıdır ve TLS komplikasyonunda ibrutinib tedavisinin sonlandırılması gerekmeyebilir.

Anahtar kelimeler: Kronik lenfositik lösemi, KLL, Ibrutinib, Tümör lizis sendromu
Received: 25 April 2021

Accepted: 12 June 2021

Online First: 18 June 2021

Corresponding Author: I. Erdogan Ozunal

ORCID: 0000-0002-5289-7134

Goztepe Prof Dr Suleyman Yalcın City Hospital, Department of Hematology, Istanbul, Turkey

isilnoktaerdogan@gmail.com

Erman Ozturk

ORCID: 0000-0002-1559-8047

Istanbul Medeniyet University Faculty of Medicine, Department of Hematology, Istanbul, Turkey 


\section{INTRODUCTION}

Tumor lysis syndrome (TLS) can occur spontaneously in patients with hematologic malignancies due to rapid cellular turnover or after cytotoxic therapy is initiated and it is characterized by electrolyte abnormalities and renal dysfunction. Chronic lymphocytic leukemia (CLL) is the most common type of leukemia in adults. TLS rarely complicates CLL because of the indolent course of $C L L^{1}$. Ibrutinib is a novel bruton kinase (BTK) inhibitor used in CLL treatment to eliminate microenvironment survival signals. Ibrutinib reduces proliferation and survival of cells and increases total $\mathrm{T}$ cell count ${ }^{2,3}$. Case reports support the fact that TLS attributed to ibrutinib monotherapy has been extremely rare ${ }^{4-6}$. We aimed to provide a concise view of TLS based on a patient diagnosed with CLL who developed grade 4 TLS after initiation of ibrutinib monotherapy.

\section{CASE REPORT}

A 69-year-old female patient with CLL presented with B symptoms (night sweats and weight loss). She had undergone treatment with chlorambucil and fludarabine cyclophosphamide rituximab (FCR) regimen seven and then four years previously, respectively. On physical examination, the patient had no lymphadenopathy but splenomegaly was detected. Physical examination of the patient and laboratory studies are summarized in Table 1 . In line with recommended novel treatment strategies for elderly del17p-positive CLL patients, the patient was started on oral ibrutinib monotherapy with daily doses of $420 \mathrm{mg}$ and oral hydration was advised. Allopurinol ( $300 \mathrm{mg} /$ day) was initiated for prophylaxis of TLS. The patient presented with abdominal pain on the third day of ibrutinib therapy. There was evidence of splenomegaly on physical examination without any additional findings. Laboratory tests revealed elevated serum creatinine, potassium, and phosphate levels; and the patient had metabolic acidosis, hyperuricemia, anemia, thrombocytopenia, and a white blood cell (WBC) count of 204.400/ $\mu \mathrm{L}$ (Table 1). She was diagnosed with TLS, and ibrutinib therapy was discontinued. The patient was started on hemodialysis because of acute renal injury, but rasburicase could not be administered due to drug procurement issues. Hemodialysis continued for two consecutive days; after the fourth day of admission, health condition of the patient was stabilized as the CLL tumor burden decreased (Figure 1). Ibrutinib therapy restarted on the seventh day at a dose of 140 $\mathrm{mg} /$ day. All symptoms of TLS resolved during the follow-up, and two weeks after re-initiating

Table 1. The patient's physical examination and laboratory values.

\begin{tabular}{|c|c|c|}
\hline Physical Examination & Laboratory Values & \\
\hline $\begin{array}{l}\text { Respiration:Clear to auscultation } \\
\text { bilaterally, no wheezing }\end{array}$ & $\begin{array}{l}\text { At admission } \\
\text { WBC: } 87000 / \mu \mathrm{L} \text { Lymphocyte: } 83000 / \mu \mathrm{L} \\
\mathrm{Hb}: 10,8 \mathrm{gr} \\
\text { Plt: } 78000 / \mu \mathrm{L}\end{array}$ & $\begin{array}{l}\text { On the } 3^{\text {rd }} \text { day of Ibrutinib therapy } \\
\text { WBC: } 204.400 / \mu \mathrm{L} \text { Lymphocyte: } 183000 / \mu \mathrm{L} \\
\mathrm{Hb}: 9,4 \mathrm{gr} \\
\text { Plt: } 86000 / \mu \mathrm{L}\end{array}$ \\
\hline $\begin{array}{l}\text { Cardiovascular: Clear S1 and S2, } \\
\text { no extra sound }\end{array}$ & $\begin{array}{l}\text { Creat: 0,76 mg/dl (N:0.7-1.2 mg/dl) } \\
\text { LDH: } 328 \text { IU (N:125-214 IU) } \\
\text { Uric acid: } 4,7 \mathrm{mg} / \mathrm{dl}(\mathrm{N}: 2,6-6 \mathrm{mg} / \mathrm{dl})\end{array}$ & $\begin{array}{l}\text { Creat: } 5,35 \mathrm{mg} / \mathrm{dl} \\
\text { Uric acid: }>33 \mathrm{mg} / \mathrm{dl} \text { Phosphorus: } 24 \mathrm{mg} / \mathrm{dl} \\
\text { (N:2,6-4,5 mg/dl) } \\
\text { Calcium: } 7,8 \mathrm{mg} / \mathrm{dl}(\mathrm{N}: 8.6-10.3 \mathrm{mg} / \mathrm{dl}) \\
\text { Potasyum:8,6 mEq/l (N:3.5-5.5 mEq/l) } \\
\text { Phosphorus: } 24 \mathrm{mg} / \mathrm{dl}(\mathrm{N}: 2,6-4,5 \mathrm{mg} / \mathrm{dl})\end{array}$ \\
\hline
\end{tabular}

$2 \mathrm{~cm}$ splenomegaly below costal edge, no hepatomegaly or $17 p$ deletion was suspected with FISH lymphadenopathy

*Abnormal values are in bold print. 


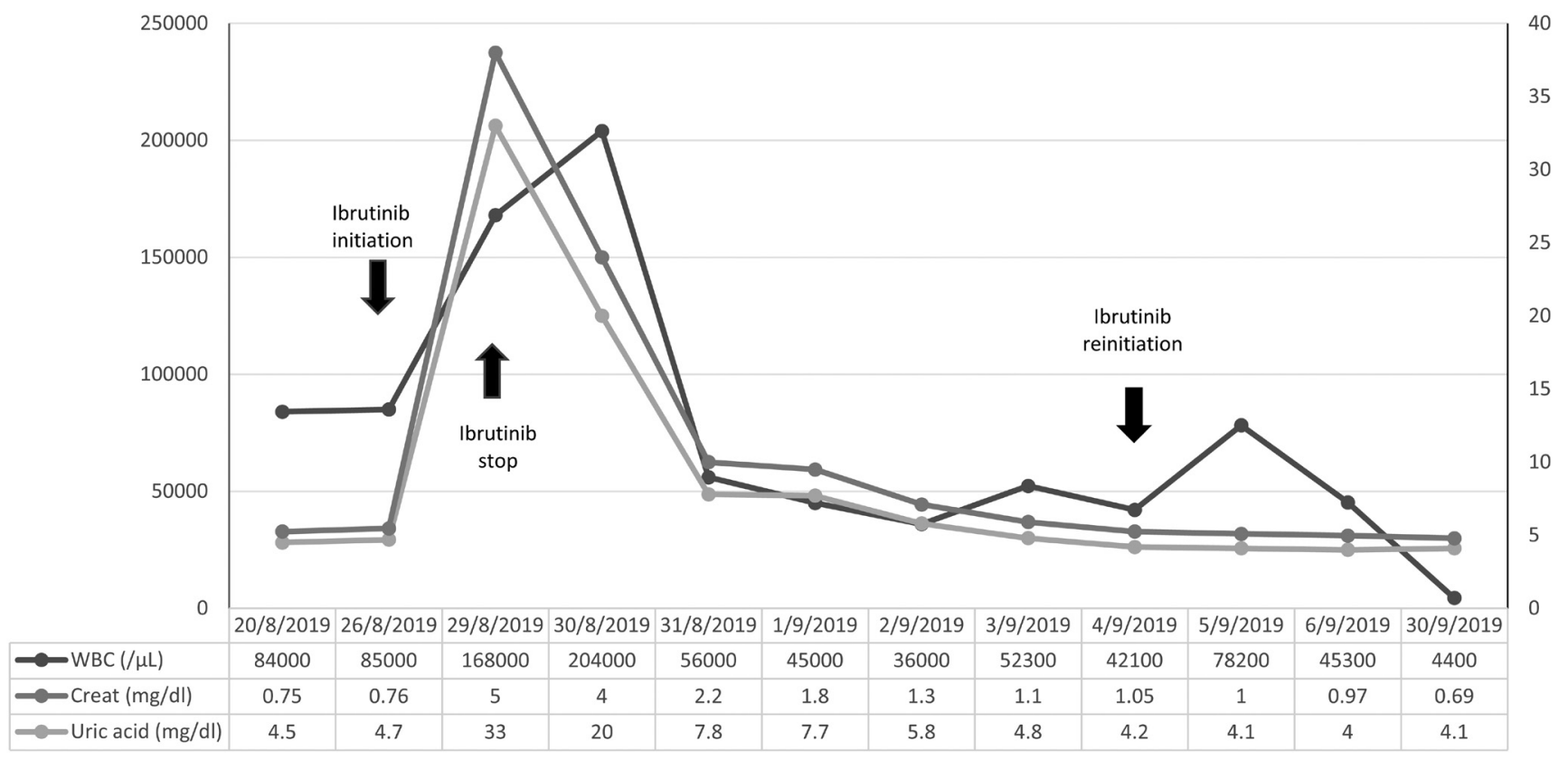

Figure 1. The patient's laboratory and treatment diary.

ibrutinib treatment, daily therapeutic dose was escalated to $280 \mathrm{mg}$. The drug dosage could not be increased further during the long-term followup due to musculoskeletal pain and arthralgia suffered by the patient. However, remission was achieved with a $280 \mathrm{mg} /$ day dose, and she was symptom-free for two years.

\section{DISCUSSION}

TLS predominantly complicates venetoclax therapy in patients diagnosed with $\mathrm{CLL}^{7}$. For this reason, dose ramp-up was explored for venetoclax. Post-hoc analysis of three major trials on ibrutinib therapy has concluded that the use of ibrutinib may reduce the risk of TLS in $\mathrm{CLL}^{8}$. None of 45 discontinuations recorded in four sequential trials of ibrutinib with 308 participants were related to TLS'. After these positive findings, ibrutinib was ratified as a new treatment approach for patients diagnosed with CLL with the advantages of survival, and a lower prediction of $\mathrm{TLS}^{10}$. However, after the widespread use of ibrutinib monotherapy complications related to TLS have been reported. In these case reports, two cases had grade 3-4 $\mathrm{TLS}^{4-6}$.
In previous investigations on the risk for TLS in CLL, no high-risk factors for TLS were found, but grade 4 TLS has emerged associated with venetoclax ${ }^{11}$. Female patients, a high number of prior therapies, Rai stages III-IV, adenopathy $\geq 10 \mathrm{~cm}$, splenomegaly, decreased albumin and increased absolute lymphocyte count, increased WBC, $\beta 2$-microglobulin, and lactate dehydrogenase were associated with risk of $\mathrm{TLS}^{12}$. Some of these risk factors were encountered in our patient, such as female gender, splenomegaly, increased WBC, and increased lactate dehydrogenase levels. The patient had hyperuricemia, anemia, thrombocytopenia with a WBC of $204.400 / \mu \mathrm{L}$ after initiation of ibrutinib. All of these findings were consistent with grade 4 TLS according to the Cairo-Bishop criteria $^{13}$. Acute kidney injury is associated with high morbidity and mortality; therefore, our patient had undergone urgent hemodialysis to prevent ongoing kidney injury due to $\operatorname{TLS}^{14}$. The health condition of the patient was stabilized after two consecutive days of hemodialysis. There is no sufficient evidence regarding whether it is appropriate to restart ibrutinib treatment after severe TLS. In the previous cases, treatment was discontinued or started again after a waiting period of 
three months $s^{5,15}$. We decided to restart ibrutinib treatment for our patient after a seven-day interruption, and TLS did not recur.

\section{CONCLUSION}

Although a limited evidence from randomized controlled trials exists with regard to lack of any TLS complication with the use of ibrutinib, TLS can develop as a serious adverse effect after initiation of ibrutinib treatment. Monitoring for TLS is essential in patients receiving ibrutinib therapy in outpatient settings. Close follow-up, initiation of prophylactic hydration, and administration of allopurinol before treatment may help reducing the risk of TLS development. Increased knowledge and awareness regarding ibrutinib-related TLS will lead to optimized TLS management after initiation of ibrutinib therapy.

\section{REFERENCE}

1. Cheson BD, Heitner Enschede S, Cerri E, et al. Tumor lysis syndrome in chronic lymphocytic leukemia with novel targeted agents. Oncologist. 2017;22:1283-91. [CrossRef]

2. Ponader S, Chen SS, Buggy JJ, et al. The Bruton tyrosine kinase inhibitor PCl-32765 thwarts chronic lymphocytic leukemia cell survival and tissue homing in vitro and in vivo. Blood. 2012;119:1182-9. [CrossRef]

3. Burger JA, Li KW, Keating MJ, et al. Leukemia cell proliferation and death in chronic lymphocytic leukemia patients on therapy with the BTK inhibitor ibrutinib. JCI Insight. 2017;2:e89904. [CrossRef]
4. Titus-Rains KS, Brown JN, Hammond JM. Ibrutinibassociated tumor lysis syndrome in chronic lymphocytic leukemia/small lymphocytic lymphoma and mantle cell lymphoma: A case series and review of the literature. J Oncol Pharm Pract. 2018;24:544-9. [CrossRef]

5. Brener ZZ, Brener H, Losev A. Bruton's tyrosine kinase inhibitors and the kidney: Focus on ibrutinib. J Oncol Pharm Pract. 2020;26:1735-7. [CrossRef]

6. Byrd JC, Furman RR, Coutre SE, et al. Targeting BTK with ibrutinib in relapsed chronic lymphocytic leukemia. N Engl J Med. 2013;369:32-42. [CrossRef]

7. Roberts AW, Davids MS, Pagel JM, et al. Targeting BCL2 with venetoclax in relapsed chronic lymphocytic leukemia. N Engl J Med. 2016;374:311-22. [CrossRef]

8. Wierda WG, Byrd JC, O'Brien S, et al. Tumour debulking and reduction in predicted risk of tumour lysis syndrome with single-agent ibrutinib in patients with chronic lymphocytic leukaemia. Br J Haematol. 2019;186:184-8. [CrossRef]

9. Maddocks KJ, Ruppert AS, Lozanski G, et al. Etiology of ibrutinib therapy discontinuation and outcomes in patients with chronic lymphocytic leukemia. JAMA Oncol. 2015;1:80-7. [CrossRef]

10. Burger JA. Treatment of chronic lymphocytic leukemia. N Engl J Med. 2020;383:460-73. [CrossRef]

11. Venclexta [internet]. Prescribing information for VENCLEXTA. Available from: https://www.rxabbvie. com/pdf/venclexta.pdf

12. Blum KA, Ruppert AS, Woyach JA, et al. Risk factors for tumor lysis syndrome in patients with chronic lymphocytic leukemia treated with the cyclin-dependent kinase inhibitor, flavopiridol. Leukemia. 2011;25:1444-51. [CrossRef]

13. Cairo MS, Bishop M. Tumour lysis syndrome: new therapeutic strategies and classification. $\mathrm{Br} J$ Haematol. 2004;127:3-11. [CrossRef]

14. Howard SC, Jones DP, Pui CH. The tumor lysis syndrome. N Engl J Med. 2011;364:1844-54. [CrossRef]

15. Kaur V, Mehta P, Johnsurd J, Govindarajan R. Ibrutinibassociated tumor lysis syndrome in a patient with chronic lymphocytic leukemia. Blood. 2014;124:3503-5. [CrossRef] 